\title{
Post-colonialism, human origins and the paradox of modernity
}

\author{
Martin Porr ${ }^{1,2, *} \&$ Jacqueline M. Matthews ${ }^{3}$
}

Post-colonial thought affects the heart of Western science. Although there is comparatively little engagement with post-colonial theory in the fields traditionally concerned with human origins or human evolution, it should be of critical importance to Palaeolithic archaeology and human evolutionary studies. Examination of recent literature dealing with so-called modern human origins highlights key neglected aspects of this discourse, namely the status of nature and rationality, and demonstrates how these aspects are entangled with ongoing political and colonial influences on the production of knowledge.

Keywords: human evolution, post-colonial theory, archaeological theory, Indigenous archaeology

\section{Introduction}

Together with the rest of the 'academy', archaeology is widely recognised as a product of colonial Western ideology and discourse. Indeed, identifying the influences of this history has brought about important and positive insights and ongoing discussions about the applicability of post-colonial thought to different aspects of archaeology (McNiven \& Russell 2005; Smith \& Wobst 2005; Moro-Abadía 2006; Hamilakis \& Duke 2007; Liebmann \& Rizvi 2008; Gosden 2012; Hamilakis 2012; Lydon \& Rizvi 2012). Despite such significant interventions, however, there is comparatively little engagement with post-colonial approaches in the fields traditionally concerned with human origins or human evolution. We argue here that post-colonial perspectives can provide critical insights into the historical and political dimensions of any understanding of the human past, and can shed light on the assumptions that form the basis of contemporary research. As post-colonial thought affects the heart of Western science, we argue that it should be of critical importance to Palaeolithic archaeology and human evolutionary studies, as well as to more recent periods.

\section{Post-colonial theory and deep time archaeology}

Currently, a post-colonial orientation can be regarded as a standard position within comparative and critical social sciences. Yet just as Western or European colonialism

1 Universität Tübingen, Institut für Ur- und Frühgeschichte und Archäologie des Mittelalters, ROCEEH-The Role of Culture in Early Expansions of Humans and Archaeology, Rümelinstraße 23, 72070 Tübingen, Germany

2 Archaeology, Centre for Rock Art Research and Management, M257, School of Social Sciences, University of Western Australia, Crawley 6009, Australia

3 Archaeology, M257, School of Social Sciences, University of Western Australia, Crawley 6009, Australia

* Author for correspondence (Email: martin.porr@ifu.uni-tuebingen.de) 
was not a monolithic ideology and found different expressions in different parts of the world, so reactions, responses and critical engagements with the consequences of that colonialism have also been variable (Said 1995; Spivak 1999; Patterson 2008). Postcolonialism as a movement in archaeology has been equally diverse and situational, and can be understood as "an active intervention that emerges from particular histories, interrogates the status quo, and moves consciously towards decolonization politically, intellectually and economically" (Nicholas \& Hollowell 2007: 62). A common thread in such approaches is to challenge "traditional colonialist epistemologies, questioning the knowledge about and the representation of colonised 'Others' that has been produced in colonial and imperial contexts" (Liebmann 2008: 5). Decolonising has far-reaching implications beyond making imperative reparations and structural changes in settled colonies (Tuck \& Yang 2012). As Rizvi (2008: 126) has argued, to "decolonise does not only index a choice to change the discipline, but also, in a very real way, is a desire to safeguard ourselves from recreating forms of imperial knowledge production".

Engaging with post-colonial theory raises profound issues related to the knowability of social forms and causalities. Such critical reflexive dimensions have been a central force directly and indirectly affecting all fields of anthropology or comparative studies of human societies (Kuper \& Marks 2011), stemming not only from post-colonial critique, but more broadly through the so-called crisis of representation (Marcus \& Fischer 1986). Particularly through engagement with Indigenous worldviews, this orientation recognises the Western framework of ontology, epistemology and knowledge fundamentally as a product of its own specific conditions, and consequently denies it the ability and authority to explain and describe humanity as a whole (Sahlins 1996; Ingold 2000; Descola 2013; Viveiros de Castro 2014; for further critique, see Todd 2016). These issues should, therefore, have relevance for the study of deep human history. Even if we define 'human origins' research very broadly, however, it is noticeable that contributions dealing with this theme are almost absent in the archaeological literature on post-colonialism or decolonisation (e.g. McNiven \& Russell 2005; Smith \& Wobst 2005; Liebmann \& Rizvi 2008; Bruchac et al. 2010; Lydon \& Rizvi 2012). We appear to be faced with the unsatisfactory situation in which a significant section of archaeology remains largely unaffected by one of the most important theoretical developments in the social sciences.

The reasons behind this situation are complex, and accounting for them is beyond the scope of this paper. We suggest that the reasons most certainly link to the disciplinary history and orientation of the fields concerned with human origins (e.g. Palaeolithic archaeology, palaeoanthropology, human evolutionary studies and so on). Within these fields, human evolution and origins are overwhelmingly viewed as natural processes and products of biological evolution, which tends to lead conceptually and epistemologically to frameworks that are rationalist, positivist and objectivist, and are, as such, reflective of a specifically Western ontology. It has been argued elsewhere that such an orientation is deeply problematic for understanding the breadth of past and present human behaviour (e.g. Ingold 2000; Gamble \& Porr 2005; Descola 2013). To develop this point further, in the following sections we make a more detailed, but preliminary, case for the value of engaging with critical post-colonial approaches in the context of human origins studies. We focus our discussion on recent literature dealing with so-called modern human origins. 
Firstly, we analyse the main underlying structures of the most widely accepted view of human origins, and highlight key neglected aspects of this discourse, namely the status of nature and rationality. Subsequently, we will demonstrate how these aspects are entangled in historical and ongoing political and colonial aspects of the production of knowledge.

\section{Nature, rationality and modern human origins}

It is not necessary to provide an extensive overview of current views on the origins of modern humans, as there have been a number of recent summaries (e.g. Nowell 2010; Dennell $\&$ Porr 2014). A central development within this vast field is the conceptual and widely accepted "decoupling of modern anatomy and modern behaviour", which was a reaction to the perceived 'lag' between the emergence of modern anatomy and modern behaviour (Nowell 2010: 438). This development has shifted the discussion into a disciplinary territory that might be described as 'cognitive archaeology', with a heavy emphasis on behavioural aspects and archaeological signifiers at the expense of anatomical and biologicaltaxonomic aspects. Nowell (2010) has summarised the most important aspects of these discussions, and we will not repeat them here (see also Garofoli 2016). Rather, we will concentrate on a critical analysis of a few interrelated recent examples.

In 2011, John Shea argued that the concept of behavioural modernity should be replaced by that of 'behavioural variability'. The former is supposedly a product of Western essentialism, while the latter gives the complexities and variabilities of past behaviours full recognition. As one of us (Porr 2011) has, however, indicated, Shea (2011: 14) argued that this behavioural variability is best approached and understood through the application of behavioural ecological methods and analyses "to seek the cost-benefit structure of the incentives underlying particular behaviours". His suggestion of a theoretical revision was, therefore, not a revision at all, but rather a shift in essentialist reasoning in which human behaviour is still explained with reference to a fixed and supposedly universal set of assumptions (Porr 2014) and a Western ontology of value (Graeber 2001).

What is neglected here is the status of nature and the status of rationality, which remain apparently non-negotiable. Consequently, the underlying relationship between nature and human behaviour remains the same, despite a contrary rhetoric, because the main elements of these arguments are reflections of deeply held attitudes and convictions in Western society. Such attitudes can be traced back well beyond the origins of modern archaeology in the nineteenth century (Thomas 2004). Stoczkowski (2002) has convincingly shown that Western scientific approaches towards human evolution and origins continue to be driven by a number of assumptions that are treated as if they were self-evident. The most important of these are environmental determinism, materialism, utilitarianism and individualism. Elsewhere, these assumptions have been dismissed as deeply problematic, given that they reinforce a universal foundation for explanations of human behaviour (Graeber 2001, 2011; Descola 2013, 2014; Viveiros de Castro 2014; Marks 2015). These critiques are fundamental challenges to the study of modern human origins, which has often been aimed at establishing the one quality that distinguishes humans from all other organisms (Proctor 2003; Malafouris 2013; Garofoli 2016), and that evokes ideas of human 'nature' widely rejected elsewhere (Marks 2009, 2013, 2015; Lewens 2012; Fuentes \& Visala 2016).

(C) Antiquity Publications Ltd, 2017 
This discourse of human exceptionalism appears to take place largely without reflecting on the historical basis of its underlying assumptions, which are connected to the deep philosophical tradition of the West and the socio-economic conditions of the modern Western world (Sahlins 1996, 2008). Ingold $(2000,2004)$ has emphasised this point with reference to the conceptualisation of human evolutionary processes. He has also drawn attention to the respective epistemological inconsistencies that have continued to plague the field since Darwin and Wallace assumed "a universal architecture underwriting the capacities of the human mind while attributing the evolution of these capacities to a theory — of variation under natural selection - that only works because the individuals of a species are endlessly variable" (Ingold 2010: 514).

The importance of these observations is that numerous authors have for some time made clear the imperialist and colonialist dimensions of this structure. Behind the assumption of a universal human nature, formulated within a framework of environmental determinism, materialism, utilitarianism and individualism "lie the longstanding imperialist conceits of a Western science that has written the essence of humanity in its own image, and that measures other people by how far they have come in living up to it" (Ingold 2004: 218). Similarly, Descola (2014: 279) has sought to challenge and reject the Western ontological orientation of naturalism and exceptionalism, where the latter is formulated in culturally specific Western terms.

But can it really be that simple? Is the scientific engagement with other cultures, other ways of being and the reconstruction of these in the past nothing but an imposition of a particular, historically determined ontology and respective epistemology? Certainly not: it is much more complicated than this. Over recent decades, numerous authors have explicated the wide range of interdependencies during the colonial period and demonstrated how these have created complex dialectic relationships on numerous levels between Western and nonWestern cultures (Wolf 1982; Fabian 1983; Said 1994, 1995). As mentioned above, it is widely accepted that these historical contingencies have deeply influenced archaeological reasoning and interpretations. It is also, however, certainly the case that these aspects have not been reflected upon substantially, nor have such interdependencies been challenged in the study of human origins and evolution.

\section{The colonial construction of Indigenous Australia and the sapient paradox}

Let us illustrate these interrelationships in a brief case study regarding the ongoing entanglements of ideas about human origins and the colonial dimensions of typical Western thought. Considering such historical connections is an important first step in any analysis aimed towards decolonising. In this case study, we juxtapose aspects of the colonial engagement in Australia with some key aspects of the recent debate about so-called modern human origins/behavioural modernity.

The work of Anderson is particularly important for understanding how the colonial encounter in Australia during the eighteenth and nineteenth centuries shaped notions of race and, accordingly, ideas about human universality, diversity, origins and nature (Anderson 2007, 2014; Anderson \& Perrin 2007; see also McNiven \& Russell 2005). The 
very first description of Indigenous Australians by William Dampier in the late seventeenth century as 'the miserablest people in the world' immediately referenced the European Enlightenment discourse about humanness and supposedly fundamental defining human characteristics. Anderson and Perrin (2007: 19) emphasised that Indigenous peoples' supposed "utter lack of improvement and, most significantly, their failure to have cultivated the land, ensured their singular place in nineteenth-century racial discourse". Subsequent encounters between the British and the Indigenous peoples of Australia were framed by the former within a discourse that assumed humanity's essence to be in a "capacity to rise above nature", and to use this capacity to transform the land through cultivation and to make proper and the most efficient use of its resources:

The colonial concept of Australia's 'idle acres' drew on notions of perfectibility and related ones in Locke's writings, of improvement, resided in the civilizational doctrine that the destiny of humanity would be realised through a developmental course of agency over the inert world of objects in nature (Anderson 2007: 95).

As colonial engagement proceeded, more doubts emerged concerning Indigenous Australians' capacity to become 'civilised', but also, more fundamentally, doubts emerged about the possibility of perfectibility in humanity. The perceived failure to 'civilise' Indigenous peoples in Australia challenged the idea of the unity of humanity and the measures that were supposed to mark human exceptionality. This conceptual crisis and insecurity supported the rise of racism in this context: "The intractable Aborigine supplied seemingly irrefutable evidence for an essential, permanent and innate racial difference, and so came to provide the strongest support for those who maintained the intrinsic inferiority of the 'dark-skinned' races" (Anderson \& Perrin 2007: 21).

One could expect that this trend towards physical or materialistic explanations of human difference was further emphasised during the course of the nineteenth century, in which humanity "was increasingly seen as embedded within processes that shaped all life on earth, human and non-human" at the expense of "divine accounts of human origins and history" (Anderson 2007: 146). Paradoxically, both Darwin and Wallace-as the main proponents of the development of increasingly naturalistic accounts of human origins_-almost desperately tried to reassert an essential human exceptionality in the face of the most extraordinary conceptual and factual challenges (Porr 2014). The important issue here is how this paradox was addressed. A key element of the solution was that universal human evolution became

figured as a 'split' process such that on the one hand, there was a sphere of cultural evolution identified with consciousness and intellect, and on the other hand, a sphere of biological evolution associated with an infrastructural physical or animal base (Anderson 2007: 147).

Not surprisingly, Indigenous Australians (and, infamously, those from Tasmania) were regarded to be closer than any other living population to this very intersection because they were thought to fulfil all requirements, both racially and culturally/technologically. In fact, when non-human (Neanderthal) remains were first discovered in 1857 they were immediately compared to contemporaneous Indigenous Australians, including most notably by Huxley (McNiven \& Russell 2005: 58-59). In the post-Darwinian period, it was assumed that 'culture' was a trait that was shared by all humans. Culture was also the (C) Antiquity Publications Ltd, 2017 
defining trait of humanity's separation from nature, and it was regarded as being reflective of 'power' and 'agency' over nature. Accordingly, the persistence of Indigenous Australians with their seemingly simple technologies remained puzzling, and they remained "in some perplexing sense, a human anomaly" because they had failed to "adequately [realise] their own humanity 'as human'" (Anderson 2007: 150).

These concerns are all related in complex ways to a range of core elements of the Western intellectual tradition that can be traced back to Classical times. Central to this are questions concerning the fundamental character of human being, human exceptionality and humanity's relationship to nature. In Classical Greek thought, humans were regarded as a part of nature. For Aristotle, humans were distinguished from all other creatures by their essential capacity for reason and their ability to understand the universal laws and structure of the universe (Descola 2013: 65). Equally, for Plato, human beings were ultimately characterised by an immortal soul separated from the mundane and physical world, which was primed to understand the actual and true characteristics of reality (Whitmarsh 2015: 133-35). Under the influence of Christianity, the theme of a division between an immortal soul and the material world (that encompassed the human body) became transformed and extended. Humans became external to nature and superior to it. Humanity's exceptionality is here related to a divine connection and, ultimately, its supernatural origin (Descola 2013: 67). This view, however, also created a tension that separated the human body from its own immaterial soul. During the Enlightenment, the place of non-European people in the natural order (the Great Chain of Being) was approached through a distinction between "an 'intellectual' series identified with Mind/Soul, and the 'sensible' series identified with Body/Brute", so that "savagery resided within all humans, as well as being embodied as certain humans" (Anderson 2007: 40). Consequently, the crucial development during the Enlightenment period was that it was not the possession of specific attributes that was seen as the source of human distinction; rather, the latter was the movement away from or out of nature (Anderson 2007: 42).

Another critical point to make is how the logic of realising human capacity is reflected in the great nineteenth-century antiquarian interest in collecting and comparing tools from across the world (Griffiths 1996; McNiven \& Russell 2005; Taylor 2017). Material culture items became reflections of the degree of freedom that different cultures and people had achieved from nature. Australian artefacts were, of course, of particular interest, because they were regarded as being closest to nature itself. As Pitt-Rivers explained, "the weapons of the Australians have found their place lowest in the scale because they assimilate most closely the natural forms" (quoted in Anderson 2007: 165). This interpretation of stone tools is further reflective of the interpretation of their makers as being as close as possible to the intersection between natural and cultural evolution, at the origin of humanity. Lubbock, in his 1865 Prehistoric times, for example, formalised Indigenous Australians as 'living fossils', and used their stone tools as a measure of the "ancientness of 'savages" (quoted in McNiven \& Russell 2005: 62-63). A key point McNiven and Russell (2005: 86) have made in regard to such comparisons is that they were not innocuous scholarly debates, but actually had devastating consequences for Indigenous peoples, as they "fulfilled an ideological demand for broad conceptual frameworks that helped to naturalise the colonial expropriation of Indigenous lands and extermination of Indigenous peoples". 
Although it is not possible to provide a deeper analysis in this paper, there are a considerable number of continuities between the understanding of human origins that was developed within the framework of colonialism discussed above, and recent understandings of so-called modern human origins. The most significant similarity appears to be the parallel distinction between a natural and cultural evolution in the one case, and between anatomical and behavioural modernity in the other. This parallelism leads to some striking similarities between the interpretation of the 'paradox' of Indigenous Australians (as outlined above) and those populations known archaeologically that were supposedly equally close to the origin of humanity.

Mellars (2006) noted, for example, that some of the earliest anatomically modern skeletons in the Near East and Ethiopia are associated with clear symbolic expressions, but only with strictly archaic, Middle Palaeolithic technologies. As such, these populations were not technologically and socio-economically equipped to "withstand competition from the long-established Neanderthal populations of Eurasia" (Mellars 2006: 9385). Consequently, Mellars (2006: 9385) was puzzled by the lack of complex technological and other behavioural patterns in these populations, even though it has to be concluded that they were already in possession of the "necessary cognitive potentials". Henshilwood (2007: 123) argued a similar point in his elaboration of the concept of "fully symbolic sapiens behaviour". He stated that "the change to anatomical modernity may not have been accompanied by behaviour that was mediated by symbolism although it could be argued that the capacity for this behaviour was already in place". At the same time, being symbolically literate is supposed to be the defining aspect of "fully symbolic sapiens behaviour", that is to say "it is the use of symbolism to mediate behaviour that is paramount and not symbolic thought alone or the capacity for symbolism" (Henshilwood 2007: 124; emphasis added).

The most explicit formulation and elaboration in this direction has been provided by Renfrew, who introduced the term 'sapient paradox' in this context (Renfrew 1996). He distinguished successive 'speciation' and 'tectonic' phases in human evolution. The former comprises the time when "in biological, i.e. genetic, terms the evolution of our species [was] effectively accomplished", which also included "the same capacity for complex speech" (Renfrew 2008: 2042). This phase apparently came to an end around 60000 years ago. The following phase saw then "the True Human Revolution" with the rise of sedentary communities and agriculture, "which in some areas soon led to the rise of urban life and of state societies and indeed to the rise of literacy" (Renfrew 2008: 2043). He termed this phase 'tectonic' with reference to the Greek word for carpenter or builder, which very much reflects his focus on post-Neolithic developments. The paradox existed for Renfrew, therefore, in the long time lag between the development of the 'biological hardware' and the respective 'software'- the skills that allowed the 'Sedentary Revolution' and subsequent developments:

Why did it all take so long? If the sapient phase of human evolution was accomplished some 60000 years ago, why did it take a further 50000 years for these sapient humans to get their act together and transform the world? That is the sapient paradox (Renfrew 2008: 2043). 
In a recent survey of the debate, Nowell (2010: 441) found that "for the majority of researchers $[. .$.$] it is symbolic behaviour including language and codified social relationships$ that defines modern behaviour". This finding is consistent with the observation that most researchers today explicitly or implicitly equate behavioural modernity with the presence of a biological capacity or potential for modern or symbolically mediated thought/thinking (Porr 2014). Apart from the fact that there is no agreement in the literature on how to recognise this capacity archaeologically, neither the possession of the capacity nor its expression in symbolic material items itself appears to be sufficient to gain full modern human status. This point is not only reflected in the cases outlined above, but also, for example, in the recent discussion about the presence of non-utilitarian and ornamental items among Neanderthal populations (Nowell 2010; Garofoli 2016: 126).

Apparently achieving full status as a modern human can only happen through making proper use of the human capacity. The arguments presented in the context of the origins of behavioural modernity mirror almost exactly those that were made about the status of Indigenous Australians in the colonial period, which measured the appropriate use of the human capacity through technological complexity and efficient use and exploitation of 'nature'. While the supposed simplicity of the material culture of Indigenous Australians was related to their position close to the origin of humanity and their unrealised potential, the earliest modern humans are equally assumed to have needed to "gradually work out their new cognitive capacities", apparently "in much the same way as that reflected in the later emergence of fully agricultural communities” (Mellars 2006: 9385). An increasingly efficient use of resources and an increase in complexity becomes an end in itself. These increases are assumed to be encapsulated in the essence of humanity from the very beginning. This analysis also unmasks that the defining characteristic of humanity within this scheme is, in fact, rationality and not 'culture' or 'symbolic thinking'. The latter two are rather viewed as means to enhance the former. In this way, cultural variability is effectively only regarded as secondary, and, in a very colonial fashion, silenced and suppressed.

\section{Conclusion}

The essentialist logic of current approaches towards modern human origins has been criticised in very effective ways (e.g. Ingold 2000; Malafouris 2013; Garofoli 2016). Very little reference has been made, however, to the deep and complex historical connections that also influence this logic. The striking similarities that can be observed between attitudes towards human origins in contemporary academic debate and at the height of European colonialism are deeply concerning. With this recognition, however, it is important to emphasise that we are not talking about contemporary researchers being colonial per se, but acknowledging rather that there is a deeper and pernicious issue at play, where the assumptive basis for dealing with such apparent paradoxes requires more critical reflection. It appears that the same logic that once formed a central element in justifying European colonial exploitation is now employed to describe the origin, historical development and character of humanity altogether. In this context, it remains unacknowledged that this very logic was itself developed out of engagement with other cultures and peoples under colonial conditions. That engagement set in motion a complex, shifting and contradictory 
interplay between the production and reproduction of sameness and otherness. In a sense, these findings are not surprising, given that the experience and realities of colonialism have shaped European and Western life for centuries. Colonialism has become a part of the very fabric of modern existence. If colonialism has shaped our bodies, tastes, passions and desires (Taussig 1993, 2009), it should not come as a surprise that it also shaped our understanding of nature and what it means to be human.

Rizvi (2015: 156) has argued that decolonisation in archaeology has to be a "process by which the internal and systemic contradictions within archaeological methodology, stemming from a colonial history, are made transparent". Although Palaeolithic archaeology might not appear to be the most pressing location for decolonisation efforts in the contemporary world, it is the field of study that is focused most explicitly on understanding what it is to be and become human. We should all be concerned if this research is affected by trajectories and paradoxes that lead us into modernity's opaque heart of darkness.

\section{Acknowledgements}

The ideas behind this paper were first presented at the 2014 TAG meeting in Manchester, and subsequently expanded and elaborated in a workshop held at the University of Western Australia in late 2015. The latter was generously funded by a Wenner-Gren Foundation Workshop Grant and a Special Grant from the Deputy Vice Chancellor of Research at the University of Western Australia. We thank the participants of both these events for their critical feedback and encouragement, as well as the two anonymous reviewers for their constructive comments on earlier versions. Martin Porr received funding from the Alexander von Humboldt-Foundation as a Senior Research Fellow, and Jacqueline Matthews received funding through an Australian Postgraduate Award during the preparation of this paper.

\section{References}

Anderson, K. 2007. Race and the crisis of humanism. London: Routledge.

- 2014. Mind over matter? On decentring the human in human geography. Cultural Geographies 21: 3-18. https://doi.org/10.1177/1474474013513409

Anderson, K. \& C. Perrin. 2007. 'The miserablest people in the world': race, humanism and the Australian Aborigine. The Australian Journal of Anthropology 18: 18-39.

https://doi.org/10.1111/j.18359310.2007.tb00075.x

Bruchac, M.M., S.M. Hart \& H.M. Wobst (ed.). 2010. Indigenous archaeologies: a reader in decolonization. Walnut Creek (CA): Left Coast.

Dennell, R.W. \& M. Porr (ed.). 2014. Southern Asia, Australia and the search for human origins. Cambridge: Cambridge University Press.

Descola, P. 2013. Beyond nature and culture. Chicago (IL): Chicago University Press.

- 2014. Modes of being and forms of predication. Hau: Journal of Ethnographic Theory 4(1): 271-80. https://doi.org/10.14318/hau4.1.012
FABIAN, J. 1983. Time and the Other: how anthropology makes its object. New York: Columbia University Press.

Fuentes, A. \& A. Visala (ed.). 2016. Conversations on human nature. Walnut Creek (CA): Left Coast.

Gamble, C.S. \& M. Porr (ed.). 2005. The hominid individual in context: archaeological investigations of Lower and Middle Palaeolithic landscapes, locales and artefacts. London: Routledge.

Garofoli, D. 2016. Cognitive archaeology without behavioral modernity: an eliminativist attempt. Quaternary International 405(A): 125-35.

Gosden, C. 2012. Post-colonial archaeology, in I. Hodder (ed.) Archaeological theory today: 251-66. Cambridge: Polity.

Graeber, D. 2001. Toward an anthropological theory of value. New York: Palgrave.

- 2011. Debt: the first 5,000 years. New York: Melville House Printing.

Griffiths, T. 1996. Hunters and collectors: the antiquarian imagination in Australia. Cambridge: Cambridge University Press.

Hamilakis, Y. 2012. Are we postcolonial yet? Tales from the battlefield. Archaeologies: Journal of the World Archaeological Congress 8: 67-76. https://doi.org/10.1007/s11759-012-9200-5 
Hamilakis, Y. \& P. Duke (ed.). 2007. Archaeology and capitalism: from ethics to politics. Walnut Creek (CA): Left Coast.

Henshilwood, C. 2007. Fully symbolic sapiens behaviour: innovations in the Middle Stone Age at Blombos Cave, South Africa, in P. Mellars, K. Boyle, O. Bar-Yosef \& C. Stringer (ed.) Rethinking the human revolution: new behavioural and biological perspectives on the origin and dispersal of modern humans: 123-32. Cambridge: McDonald Institute for Archaeological Research.

INGOLD, T. 2000. The perception of the environment: essays in livelihood, dwelling and skill. London: Routledge. https://doi.org/10.4324/9780203466025

- 2004. Between biology and culture: the meaning of evolution in a relational world. Social Anthropology 12: 209-21. https://doi.org/10.1017/S0964028204000291

-2010 . What is a human being? American Anthropologist 112: 513-14.

Kuper, A. \& J. Marks. 2011. Anthropologists unite! Nature 470: 166-68. https://doi.org/10.1038/470166a

Lewens, T. 2012. Human nature: the very idea. Philosophy and Technology 25: 459-74. https://doi.org/10.1007/s13347-012-0063-x

LiebmanN, M. 2008. Introduction: the intersections of archaeology and postcolonial studies, in M. Liebmann \& U.Z. Rizvi (ed.) Archaeology and the postcolonial critique: 1-20. Lanham (MD): AltaMira.

Liebmann, M. \& U.Z. Rizvi (ed.). 2008. Archaeology and the postcolonial critique. Lanham (MD): AltaMira.

Lydon, J. \& U.Z. Rizvi (ed.). 2012. Handbook of postcolonial archaeology. Walnut Creek (CA): Left Coast.

Malafouris, L. 2013. How things shape the mind: a theory of material engagement. Cambridge (MA): MIT.

Marcus, G.E. \& M.M.J. Fischer (ed.). 1986. Anthropology as cultural critique: an experimental moment in the human sciences. Chicago (IL): University of Chicago Press.

Marks, J. 2009. The nature of humanness, in B. Cunliffe, C. Gosden \& R.A. Joyce (ed.) The Oxford handbook of archaeology: 237-53. Oxford: Oxford University Press. https://doi.org/10.1093/ oxfordhb/9780199271016.013.0010

- 2013. The nature/culture of genetic facts. Annual Review of Anthropology 42: 247-67. https://doi.org/10.1146/annurev-anthro-092412155558

- 2015. Tales of the ex-apes: how we think about human evolution. Oakland: University of California Press.
McNiven, I.J. \& L. Russell. 2005. Appropriated pasts: Indigenous peoples and the colonial culture of archaeology. Lanham (MD): AltaMira.

Mellars, P. 2006. Why did modern human populations disperse from Africa ca. 60,000 years ago? A new model. Proceedings of the National Academy of Sciences of the USA 103: 9381-86. https://doi.org/10.1073/pnas.0510792103

Moro-Abadía, O. 2006. The history of archaeology as a 'colonial discourse'. Bulletin of the History of Archaeology 16(2): 4-17. https://doi.org/10.5334/bha.16202

Nicholas, G.P. \& J. Hollowell. 2007. Ethical challenges to a postcolonial archaeology, in Y. Hamilakis \& P. Duke (ed.) Archaeology and capitalism: from ethics to politics: 59-82. Walnut Creek (CA): Left Coast.

Nowell, A. 2010. Defining behavioral modernity in the context of Neandertal and anatomically modern human populations. Annual Review of Anthropology 39: 437-52.

Patterson, T.C. 2008. A brief history of postcolonial theory and implications for archaeology, in M. Liebmann \& U.Z. Rizvi (ed.) Archaeology and the postcolonial critique: 21-34. Lanham (MD): AltaMira.

Porr, M. 2011. One step forward, two steps back: the issue of 'behavioral modernity' again: a comment on Shea. Current Anthropology 52: 581-82. https://doi.org/10.1086/660845

- 2014. Essential questions: 'modern humans' and the capacity for modernity, in R. Dennell \& M. Porr (ed.) Southern Asia, Australia and the search for human origins: 257-64. Cambridge: Cambridge University Press.

Proctor, R.N. 2003. Three roots of human recency: molecular anthropology, the refigured Acheulean, and the UNESCO response to Auschwitz. Current Anthropology 44: 213-39. https://doi.org/10.1086/346029

Renfrew, C. 1996. The sapient behaviour paradox: how to test for potential?, in P. Mellars \& K. Gibson (ed.) Modelling the early human mind: 11-15. Cambridge: McDonald Institute for Archaeological Research.

- 2008. Neuroscience, evolution and the sapient paradox: the factuality of value and the sacred. Philosophical Transactions of the Royal Society B 363: 2041-47.

Rizvi, U.Z. 2008. Decolonizing methodologies as strategies of practice: operationalizing the postcolonial critique in the archaeology of Rajasthan, in M. Liebmann \& U.Z. Rizvi (ed.) Archaeology and the postcolonial critique: 109-27. Lanham (MD): AltaMira. 
- 2015. Decolonizing archaeology: on the global heritage of epistemic laziness, in O. Kholeif (ed.) Two days after forever: a reader on the choreography of time: 154-64. Berlin: Sternberg.

SAHLins, M. 1996. The sadness of sweetness: the native anthropology of Western cosmology. Current Anthropology 37: 395-428. https://doi.org/10.1086/204503

- 2008. The Western illusion of human nature. Chicago (IL): Prickly Paradigm.

SAID, E.W. 1994 [1993].Culture and imperialism. London: Vintage.

- 1995 [1978].Orientalism. London: Penguin.

Shea, J.J. 2011. Homo sapiens is as Homo sapiens was. Current Anthropology 52: 1-35. https://doi.org/10.1086/658067

Sмiтн, C. \& H.M. Woвsт (ed.). 2005. Indigenous archaeologies: decolonizing theory and practice. London: Routledge.

SPIVAK, G.C. 1999. Toward a history of the vanishing present. Cambridge (MA): Harvard University Press.

STOczкоwsKI, W. 2002. Explaining human origins: myth, imagination and conjecture. Cambridge: Cambridge University Press. https://doi.org/10.1017/CBO9781139164399
TAussig, M. 1993. Mimesis and alterity: a particular history of the senses. London: Routledge.

- 2009. What color is the sacred? Chicago (IL): University of Chicago Press.

TAYLOR, R. 2017. Into the heart of Tasmania: a search for human antiquity. Melbourne: Melbourne University Press.

Thомаs, J. 2004. Archaeology and modernity. London: Routledge.

TodD, Z. 2016. An Indigenous feminist's take on the ontological turn: 'ontology' is just another word for colonialism. Journal of Historical Sociology 29: 4-22. https://doi.org/10.1111/johs.12124

Tuck, E. \& K.W. Yang. 2012. Decolonization is not a metaphor. Decolonization: Indigeneity, Education \& Society 1(1): 1-40.

Viveiros de Castro, E. 2014. Cannibal metaphysics: for a post-structural anthropology. Minneapolis (MN): Univocal.

Whitmarsh, T. 2015. Battling the gods: atheism in the ancient world. New York: Alfred E. Knopf.

Wolf, E.R. 1982. Europe and the people without history. Berkeley: University of California Press.

Received: 6 June 2016; Accepted: 22 September 2016; Revised: 23 September 2016

(C) Antiquity Publications Ltd, 2017 